\title{
External Iliac Lymph Node
}

National Cancer Institute

\section{Source}

National Cancer Institute. External Iliac Lymph Node. NCI Thesaurus. Code C88143.

A lymph node located along the external iliac artery. 